\section{A reconfiguração do movimento ecumênico e a busca de uma teologia ecumênica na América Latina*}

\section{Elias Wolff ${ }^{a}$}

Pontifícia Universidade Católica do Paraná (Pucpr), Brasil http://orcid.org/0000-0003-2479-2340

RECEBIDO: 23-08-18. APROVADO: 11-12-18

Resumo: O movimento ecumênico é uma realidade dinâmica e em contínua transformação a partir dos novos tempos, novos contextos e novos sujeitos que se integram no diálogo sobre a oikoumene, como as culturas e as religióes. $\mathrm{O}$ objetivo deste estudo é investigar como esse fato implica em uma reconfiguração do universo semântico do conceito "ecumenismo" em nossos tempos. E procede analisando os desafios e as contribuiçóes que os novos atores culturais e religiosos apresentam para o diálogo ecumênico na região. Conclui que emergem daí significativos elementos para a elaboração de uma teologia ecumênica latino-americana.

Palabras clave: Ecumenismo; diálogo ecumênico; religiẫo na América Latina; teologia ecumênica.
The Reconfiguration of the Ecumenical Movement and the Search for an Ecumenical Theology in Latin America

Aвstract: The ecumenical movement is a dynamic reality in constant transformation according to the new times, the new contexts and the new subjects that are integrated in the dialogue about oikoumene, such as cultures and religions. The objective of this study is to investigate how this fact affects the reconfiguration of the semantic universe of the concept "ecumenism" nowdays. It proceeds by analyzing the challenges and contributions that the new cultural and religious actors present to ecumenical dialogue in the continent; and it concludes that significant elements emerge for the elaboration of a Latin American ecumenical theology.

Key Words: Ecumenism; Ecumenical dialogue; Religion in Latin America; Ecumenical Theology.

\section{Cómo CITAR:}

Wolff, Elias. "A reconfiguração do movimento ecumênico e a busca de uma teologia ecumênica na América Latina”.. Theologica Xaveriana 189 (2020): 1-XX. https://doi.org/10.11144/javeriana.tx70. rmebte

\title{
ReCONHECIMENTO
}

O artigo é de investigação, vinculado ao Projeto de "Pesquisa O movimento ecumênico brasileiro, 2000 a 2015". O presente trabalho foi realizado com apoio da Coordenação de Aperfeiçoamento de Pessoal de Nível Superior - Brasil, Capes - Código de Financiamento 001.

*Artigo de investigação

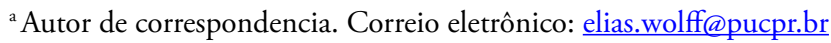




\section{Introdução}

$\mathrm{O}$ desenvolvimento do projeto de pesquisa "O movimento ecumênico brasileiro 2000-2015”, constata que as concepçóes e as práticas ecumênicas se reconfiguram em nossos tempos, mostrando que o ecumenismo é uma realidade complexa, dinâmica e em constante transformação. Essa é uma realidade do ecumenismo em todo o mundo.

Para compreender esse dado na realidade local, a pesquisa se amplia agora para o movimento ecumênico latino-americano, verificando como ele é impactado por novas dinâmicas e novos paradigmas ecumênicos a partir da interculturalidade, do pluralismo religioso e da inserção social do diálogo. Identificar esses elementos requer uma apurada análise do ecumenismo tal como tem sido desenvolvido pelas igrejas do continente, mas também dos novos horizontes que hoje se abrem para a oikoumene. Essa análise é feita com o método dialógico que possibilita reconhecer e dialogar com novos protagonistas, novas concepçóes e novas perspectivas da oikoumene na atualidade, numa interação entre ecumenicistas brasileiros e latino-americanos.

Há um princípio realista do ecumenismo que se afirma a partir da realidade concreta de cada uma das identidades em diálogo. E um princípio utópico, que crê ser possível a convivência fraterna de todas as identidades que constroem a oikoumene. Esses dois princípios se relacionam em nosso estudo. Dessa constatação emergem dois prementes desafios para as igrejas: o primeiro é o de manter a concepção clássica do ecumenismo, entendido como busca da unidade cristã. O segundo é de lançar-se decididamente para a interação com as culturas e as religióes que também percorrem os caminhos do diálogo, realizando iniciativas de convivência e cooperação para que o mundo seja realmente a casa onde todos possam conviver na justiça, na paz e na liberdade.

E esse processo precisa ser fundamentado teologicamente. Para isso não basta importar para as igrejas latino-americanas postulados teológicos de outras latitudes. Em diálogo com esses, urge desenvolver uma teologia ecumênica latino-americana, o que aqui propomos retomando a perspectiva da libertaçáo própria da teologia desenvolvida no continente, enriquecida pelos novos horizontes e as novas perspectivas teológicas atuais.

\section{Novas dinâmicas do ecumenismo na atualidade}

O conceito "ecumenismo" recebe diferentes compreensões conforme o uso que dele é feito por diferentes sujeitos em diferentes tempos e situaçôes. Mas indica sempre a comunhão de cosmovisões, opções, interesses, estilos de vida, com sentido econômico, político, cultural, ético e religioso. Desde o final do século XIX a perspectiva cristã 
do ecumenismo foi a que mais se desenvolveu, no sentido de busca da unidade da Igreja de Cristo. Atualmente o movimento ecumênico cristáo convive com diversas formas de pensar a oikoumene num mundo globalizado, planetário, onde tudo se relaciona.

Os esforços ecumênicos atuais são impulsionados pelo contexto da globalização que apresenta novas e favoráveis possibilidades de encontro, interação e intercâmbio entre as diferenças, dentro e fora do âmbito cristão. Já não há mais espaço para a indiferença em relação à existência do outro, que não é apenas um indivíduo concreto, mas o seu mundo cultural, étnico, político, econômico e religioso. Culturas, religiôes e espiritualidades outrora distantes e desconhecidas, encontram-se hoje convivendo num mesmo espaço sociocultural. Impóe-se a exigência do reconhecimento.

A emergência de novos atores globais redimensiona a concepção da realidade e da forma de nela estar apresentando novas concepçóes da ecumene. O que se constata é a mudança de paradigma ou de eixo hermenêutico da realidade da ecumene. Identificamos quatro propostas:

1. O ecumenismo secular: propóe novas formas de estar no mundo e que "um outro mundo é possível", prescindido de fundamentação que transcenda elementos concretos da existência social. Bastam princípios básicos comuns, como uma ética mundial que sustente relaçóes simétricas entre indivíduos de uma mesma sociedade, ou entre povos, ou na relação com a criação.

O ecumenismo de justiça e o ecumenismo das culturas convergem para a construção da oikoumene. As situaçôes de empobrecimento, fome, desemprego, negação dos direitos humanos, exigem um ecumenismo social ou ecumenismo político, com projetos de ação capazes de transformar as estruturas sociais atuais e modelar novas sociedades ${ }^{1}$. A gravidade dos problemas ambientais causados pelo uso irresponsável dos recursos naturais e suas consequências como a poluição ambiental, as dificuldades de acesso à água potável e o aquecimento global, entre outros, exigem um ecumenismo ecológico ou planetário, que defenda não apenas a vida dos povos, mas todas as formas de vida presentes no cosmos.

2. O ecumenismo inter-religioso: sustenta o paradigma ecumênico em princípios religiosos, de fé, mas não se concentra em nenhuma tradição religiosa. Enfrenta os desafios do pluralismo religioso, fazendo com que se extrapole a compreensão cristã e eclesiológica da realidade, abrindo sistemas teológicos que por séculos sustentaram a compreensão da ecumene, e se pensa num ecumenismo assentado no princípio

\footnotetext{
${ }^{1}$ Quintero Pérez, “Oikoumene: Venturas y desventuras en Ia antesala dei tercer milênio” 44ss.; Westehelle, "Una sancta: a unidade da Igreja na divisão social”, 43.
} 
teocêntrico como o que melhor pode responder às interpelações de uma realidade religiosa plural.

3. O ecumenismo cristão: aparece atualmente com duas perspectivas:

- Em continuidade com a história do movimento ecumênico clássico busca a unidade da Igreja, congregando as pessoas que crêem em Cristo na confissão de uma mesma fé, a qual é celebrada pelos mesmos sacramentos e animada pelos serviços apostólicos reconhecidos pelas diferentes igrejas.

- Um ecumenismo reinocêntrico e escatológico, que afirma uma postura inclusiva do pluralismo religioso assentando a cristologia em novos princípios hermenêuticos que possibilitam uma perspectiva mais trinitária da compreensão da ecumene, respondendo às exigências de um teocentrismo cristão.

4. O ecumenismo espiritual: busca vincular diferentes motivaçóes fundantes da existência das pessoas, propondo um horizonte holístico no qual essas motivaçóes comungam em seus princípios gerais sobre a origem, o sentido e o final da existência. Para além do diálogo teológico, importa explicitar as convergências espirituais entre os diferentes credos, base e motor da convivência social dos povos.

Disso decorre que muitas são as formas de agir ecumenicamente. Por parte das igrejas, mantém-se a busca de um ecumenismo institucional que visa articular formalmente o diálogo sobre conteúdos doutrinais com a atuação de peritos e das lideranças religiosas. Mas para muitos, os esforços ecumênicos nessa direçâo já atingiram seus limites, os resultados alcançados são extremamente tímidos em relação à meta que se busca e há certo descrédito de seus métodos e objetivos.

Já as propostas secular, inter-religiosa e espiritual do ecumenismo ganham espaços em diferentes ambientes da sociedade, das tradiçôes religiosas e das correntes de espiritualidades contemporâneas. Movidos pela mobilização dos movimentos populares propóem um "ecumenismo de base" que dialoga sobre questôes sociais e ambientais, um ecumenismo de justiça, ou ecumenismo de vida em sentido amplo, para além de um ecumenismo doutrinal.

\section{A construção de novos paradigmas ecumênicos}

Contextualizando a nossa reflexão na América Latina, é importante considerar mais de perto alguns elementos dessas especificidades na construçáo da oikoumene. 


\section{A interculturalidade}

O tempo em que vivemos apresenta mudanças paradigmáticas que potencializam e expandem os horizontes do ecumenismo, considerando os fenômenos da globalização, do pluralismo religioso e cultural com suas implicaçóes para toda a humanidade. Nesse contexto, o projeto ecumênico precisa ir hoje além das igrejas. As relaçóes precisam incluir a comunidade humana inteira, suas questôes raciais, étnicas, religiosas, políticas, de gênero e de culturas. $O$ paradigma ecumênico atual se constrói pelo repensamento de conhecimentos e métodos de compreensão dos "outros" e de suas práticas sociais e religiosas.

Mais ainda, precisa abordar a vida de toda a criação, a "oikoumene de Deus deve ser entendida não só à imagem política e social do Reino, mas também à imagem holística da nova criaçáo, dos novos céus e da nova terra" ${ }^{2}$. Nada do que diz respeito à vida da humanidade e da criação deve ficar fora de uma nova visão da oikoumene. Daqui o sentido de "casa comum" como o lugar da comunhão de todas as realidades que dizem respeito à vida das pessoas e da criaçáo.

Assim, a teologia ecumênica é mais que um diálogo intra-cristão e mesmo inter-religioso. Aponta para um frutífero encontro das culturas, entendidas como diferentes modos de viver e de conviver. É a proposta da interculturalidade, em suas diferentes perspectivas, filosófica, teológica, antropológica, etc., como paradigma ecumênico. Acolhemos a compreensão que Raúl Fornet-Betancourt apresenta de interculturalidade, como

Aquela postura ou disposição pela qual o ser humano se capacita para e se habitua a viver "suas" referências identitárias em relação com os chamados "outros", quer dizer, compartindo-as em convivência com eles. Daí que se trata de uma atitude que abre o ser humano e o impulsiona a um processo de reaprendizagem e recolocação cultural e contextual. ${ }^{3}$

Isso exige, de um lado, o conhecimento da própria cultura, ou seja, do próprio modo de ser e do contexto em que se vive, entendendo que a própria cultura se dá por uma diversidade de expressóes culturais. De outro lado, exige-se o reconhecimento da cultura do outro e do seu contexto.

O autoconhecimento e o reconhecimento do outro exigem relações simétricas na valorizaçáo das diferenças, considerando o valor próprio sem negar o valor do outro. A interculturalidade é mais que a convivência das culturas, que seria uma mera aceitação da diferença, do multiculturalismo, pelo exercício da tolerância. Uma relação

\footnotetext{
${ }^{2}$ Raiser, "O Conselho Mundial e os novos desafios para o movimento ecumênico", 281.

${ }^{3}$ Fornet-Betancourt, Interculturalidade. Crítica, diálogo e perspectivas, 13.
} 
intercultural supõe o encontro, a interação, o diálogo, o intercâmbio, o enriquecimento mútuo entre as culturas. Passa da tolerância do outro para a aceitaçáo, do simples conhecer para o reconhecer e promover seus valores.

Por interculturalidade entendemos, então, a relação entre diferentes sistemas simbólicos que expressam modos de vida de pessoas, grupos, civilizaçóes. Para que essa relação seja positiva, é necessário que se afirme a justiça cultural que rompe com pretensóes imperialistas de uma cultura sobre outras, superando hegemonias culturais de povos dominantes que se impóe assimilando as culturas dos dominados.

Sobretudo em nossos tempos, urge uma postura crítica da cultura neoliberal globalizada que homogeneiza cosmovisóes e padróes de comportamentos, desqualificando as crenças, os valores e os significados de civilizaçôes inteiras. Trata-se de exercitar um olhar crítico aos sistemas culturais totalizantes, às posturas colonialistas e neocolonialistas que negam as diferenças em favor de projetos políticos, econômicos e religiosos monoculturais. A desconstrução do colonialismo cultural - decolonização cultural - exige a disposiçáo para a escuta do outro, marginalizado, excluído, discriminado. Essa perspectiva cultural crítica embasa relaçóes libertadoras entre pessoas e povos.

A interculturalidade é, assim, a base e ao mesmo tempo o eixo condutor de um paradigma ecumênico consistente para pensar a fé. Ela é condição da interação, do intercâmbio e do diálogo entre as crenças. O diálogo cultural que possibilita o respeito, o aprendizado e a equidade entre diferentes sistemas de vida, abre espaço para o diálogo entre as diferentes concepções religiosas que se expressam culturalmente. Toda religião tem um sistema cultural que a sustenta e expressa por linguagens, símbolos, gestos, que compóe o universo simbólico das pessoas e dos povos. Uma religião é sempre culturalmente mediada.

Por isso, não há encontro das religióes sem encontro das culturas nas quais elas se assentam e pelas quais se manifestam. A interculturalidade é, assim, um fator importante para o encontro das diferentes formas de crer. O diálogo intercultural possibilita identificar e superar os elementos de discriminação, preconceito e intolerância religiosa que se expressam culturalmente. $\mathrm{Na}$ perspectiva cristã, é o que possibilita afirmar um "Deus que supera a limitação das culturas e a barreira das religióes, que se encarna no mundo em Jesus de Nazaré e nos envia para a caminhada com o outro, em solidariedade, acompanhamento e destinos comuns"4.

${ }^{4}$ Zwetsch, "Teologias da libertação e interculturalidade”, 126. 


\section{A interculturalidade no contexto latino-americano}

$\mathrm{Na}$ América Latina, a interculturalidade é fundamental para que se faça justiça para com as culturas, os saberes e as crenças das minorias sufocadas pelo imperialismo cultural globalizado, como os povos indígenas e afro-americanos, as pessoas idosas, as mulheres, as juventudes e as crianças que formam as classes sociais empobrecidas. Supóe um processo de decolonização, criticando o olhar que o colonizador ocidental europeu cristalizou sobre o "outro" que o torna um "mesmo" pela assimilação totalizante do sentido. E propóe uma nova visão cultural e histórica do outro, um "revelar" sua verdade, restituindo-lhe a voz e a ação livres, condiçóes para resgatar a sua dignidade.

"A crítica do colonialismo é desenvolvimento de uma hermenêutica da libertação histórica pelo qual o 'índio mudo' redescobre sua palavra, e ou o 'negro desconhe-

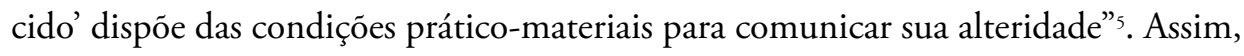
os povos historicamente submetidos deixam de ser "interpretados" para se tornarem "intérpretes" de si mesmos e da história, "como sujeito que me oferece uma perspectiva a partir da qual eu posso me interpretar e ver"6. Libertar as vozes silenciadas, ajudar o agir amarrado, promover o pensar reprimido é superar o solipsismo do pensamento único. "Pensar" não é um ato isolado, mas "um exercício continuado de convocação de vozes e re-perspectivas de saberes e sabedorias" . A compreensão da realidade se dá, assim, por uma comunhão de saberes, um saber intercultural.

Isso não acontece sem permitir que o outro seja outro, assuma e expresse a sua identidade. Trata-se de evitar fazer do nosso mundo categorial o centro da verdade do outro, definido e determinado a partir do eu, criando condiçóes para que "os outros" se expressem, "articulem seu logos sem pressões ou deformaçóes impostas".

As igrejas, religiōes e espiritualidades muito têm a contribuir para isso. Ao colocarem na mesa do diálogo suas convicçôes, suas teologias, seus princípios éticos e suas práticas de espiritualidade, estão possibilitando o diálogo sobre as formas culturais nas quais esses elementos se revestem e se expressam e, desse modo, favorecem para que as pessoas e as comunidades que por elas se manifestam também entrem num diálogo enriquecedor. No diálogo ecumênico, interculturalidade e inter-religiosidade vão juntas. As religióes se encontram na medida em que as culturas se encontrarem.

\footnotetext{
${ }^{5}$ Fornet-Betancourt, Questöes de método para uma filosofia intercultural a partir da Ibero-América, 15.

${ }^{6}$ Ibid., 49.

${ }^{7}$ Ibid., 52.

${ }^{8}$ Ibid., 20.
} 
O espaço do encontro é o inter, "no qual o diverso permanece primariamente indeterminado e no qual a gente se abstém do juízo e da definição"”.

Ali acontece o exercício de ver e deixar ser visto, de falar e de ouvir, na gratuidade e liberdade que permite ao ser revelar-se de forma espontânea e íntegra. A recepção do que se manifesta possibilita o reconhecimento dos seus valores identitários. E então se inicia e se fortalece a caminhada para um crescimento conjunto das diferenças. As religiốes contribuem para isso mostrando que o encontro mais profundo se dá no nível da espiritualidade. Com suas místicas, elas expandem para as culturas as atitudes de compaixáo, cuidado, solidariedade, fraternidade e compromissos comuns que sustentam a oikoumene.

\section{pluralismo religioso}

Como vimos, na esteira do pluralismo sócio-cultural das sociedades globalizadas, torna-se expressivo o pluralismo religioso e espiritual, com implicaçôes que não podem ser desconsideradas pelo diálogo que pretende plasmar a oikoumene. São implicaçôes desafiadoras, mas que se apresentam também como contribuiçóes significativas para esse fim, com novos sujeitos, novos conteúdos, novas perspectivas e novas finalidades. Não há como excluir da oikoumene essas tantas vivências apenas porque não acontecem na perspectiva claramente cristá.

Por outro lado, também não se deve confundir as propostas, desconsiderando as diferenças, divergências e até mesmo contradiçôes. Para além da exclusão e da confusão, o que se faz necessário é distinguir as diferentes formas de se estar na oikoumene, sem pretender construir oikoumenes à parte.

A natureza específica de cada agir ecumênico não deve impedir de compreender que a oikia/casa que visamos é uma só, e nela todos somos chamados a conviver. Afinal, uma casa pode ter diferentes cômodos, como sugere Konrad Raiser ${ }^{10}$, mas é a mesma casa. Então os encontros dos seus habitantes torna-se inevitável. Eles podem acontecer em diferentes cômodos: na cozinha, na área de serviço, na sala, nos corredores, na porta de entrada. Os encontros podem acontecer também fora da casa, na garagem, no pátio, na rua. Quem vive na casa, convive, não se pode ficar preso ao próprio quarto por toda uma vida, resistindo encontrar-se com os demais. Esses encontros mostram a dinâmica da convivência e não obstante possíveis tensôes e conflitos, quando acontecem na liberdade e na maturidade dos convivas, são fortemente enriquecedores do ambiente comum.

\footnotetext{
${ }^{9}$ Becka, Interculturalidade no pensamento de Raúl Fornet-Betancourt, 46.

${ }^{10}$ Raiser, "O Conselho Mundial e os novos desafios para o movimento ecumênico”, 276-281.
} 
Tal é o que se constata nas iniciativas de diálogo inter-religioso no continente. Embora ainda incipiente, esse diálogo existe e tem como sujeitos as religióes dos povos indígenas e das tradiçóes afro, as grandes religiôes da Ásia e do Oriente, as novas espiritualidades contemporâneas de diferentes matrizes, sobretudo asiáticas.

A pauta do diálogo costuma focar em questôes sociais e ambientais, como urgências para o ecumenismo de justiça que os nossos povos precisam. $\mathrm{O}$ tom profético propóe tanto uma crítica aos postulados teóricos que legitimam as estruturas sociais, quanto uma ação transformadora dessas estruturas, sem o que não se realiza o ecumenismo de vida que a todos possibilita a convivência na liberdade e na igualdade.

\section{As religiões indígenas e afro-americanas na oikoumene}

As religiōes indígenas e afro-americanas são mais que patrimônio dos povos deste continente, são riquezas para toda a humanidade. Com suas crenças, seus ritos, suas liturgias, os índios e os descendentes das tradiçóes africanas imprimem uma marca no universo religioso e cultural de toda a humanidade. Considerando que "o elemento mais comum entre os humanos talvez seja a linguagem e o sentimento religioso" ${ }^{11}$, a história dos povos é também uma história de suas crenças religiosas. Mesmo que algumas culturas não usem o conceito religião, o fato está sempre presente. E as religióes afro-americanas têm o seu lugar na história religiosa da humanidade.

Como dito, o pluralismo é uma realidade dentro das religiôes dos povos indígenas e africanos, apresentando alternativas para a experiência do sagrado. Isso não é algo problemático ou um mal a eliminar. O desafio teológico é compreender esse pluralismo como manifestação da riqueza multiforme do Espírito. Isso exige uma atitude de abertura aos diversos dons que Deus concede aos povos, o que implica reconhecer a experiência do sagrado na religião do outro. As religióes indígenas e de tradiçōes afro já praticam esse reconhecimento. Por suas próprias características elas são abertas ao diálogo e à interlocução, como religiōes inclusivas que mantendo a integridade da sua proposta original, valorizam e até assumem as riquezas de outras religióes, o que se expressa, por exemplo, no sincretismo e na dupla pertença.

Para muitos, isso é visto negativamente. Mas não o é para as culturas dos povos indígenas e negros. No encontro da fé cristã com as religióes indígenas e africanas o sincretismo foi uma consequência inevitável ${ }^{12}$. E "libertar" essas religióes do sincretismo

\footnotetext{
${ }^{11}$ Padre Toninho, "Porque somos militantes desta causa".

${ }^{12}$ Há várias compreensóes de sincretismo, como reinterpretação ou mudança do significado de antigas tradiçôes pela inclusão de novos valores ou vice-versa; ou fusão de várias tradiçôes; ou refundição, como abertura de uma religião a outras, assimilando-as, reinterpretando-as, refundindo-as a partir dos
} 
é romper com a Igreja e o cristianismo presente na vida de muitos de seus seguidores. Eles dificilmente farão esse rompimento. O caminho melhor é o da "enculturação" ou "refundição", que pode levar a uma espécie de "purificação" do contraditório, excessos no sincretismo.

Acolhe-se, assim, a contribuição dessas religiōes para a oikoumene. A primeira contribuição é a afirmação da própria identidade. A oikoumene se constrói pela relação de identidades maduras. Para os povos índios e negros da América Latina, a identidade é questão de consciência, atitude de responsabilidade frente à vida, um modo de ser e de viver. É um movimento por cidadania, um jeito de fazer política e pensar a sociedade toda.

No Brasil, uma forte expressão disso foram os quilombos, espaços de liberdade entre negros, índios e brancos pobres. Todos abraçavam um projeto pluri-étnico a fim de serem construtores de uma nova sociedade igualitária e pluri-étnica. Nos quilombos os negros desenvolveram sua própria organização social, recuperaram suas tradiçôes culturais e religiosas. Atualmente, existe uma variedade de organizaçôes da população negra que busca mudar o comportamento racista e preconceituoso das sociedades latino-americanas.

Há muitas outras fundamentais contribuiçóes desses povos para a oikoumene, como a prática da solidariedade na dor e na alegria. Essa solidariedade tem raízes culturais e teológico- espirituais, e se realiza ao som do tambor, na dança, na acolhida e na partilha; a vida comunitária e familiar: para os índios e os negros, a família confunde-se com a comunidade - filhos, netos, enteados, vizinhos e outros mais que se achegam. O africano e o indígena é um "ser com" e "vive com", essencialmente comunitário, onde encontra sua força vital; os princípios éticos fundamentais, enraizados em conceitos chaves como vida, solidariedade, simplicidade, força e harmonia; a integração com a natureza, com quem se relaciona e cuida com o sentimento de

critérios de sua própria identidade. E há duas principais posturas em relação ao sincretismo: rejeição, como algo suspeito, com conotação pejorativa de mistura, colagem, impureza, contaminaçáo. Aqui a compreensão da fé parte de uma religião pronta, verdadeira em si mesma, sem mescla, mistura, confusão, expressão direta da divindade através de intérpretes autorizados. O perigo é a abstração da fé de seu contexto histórico. de simpatia, compreendendo-o a partir da noçáo de memória coletiva como um sistema estruturado, no qual cada elemento tem um lugar determinado. O sentido global do conjunto é resultado das interaçôes dos vários elementos entre si (Ortiz, A consciência fragmentada, 14.). Nos meios católicos prevalece a tendência em usar cada vez menos esse termo, trocando-o pelo de inculturação, visando a descoberta do núcleo da revelação divina no centro de revestimentos passageiros, e compreendendo o caráter sincrético do catolicismo na base, como possibilidade da redescoberta do verdadeiro cristianismo "sob certas formas adulteradas pela história" (Hoornaert, Formação do catolicismo brasileiro 1550-1800, 29; Celam, Documento de Santo Domingo 230-231; 248-251.) . 
pertença, numa integração existencial, uma vez que tudo na cosmovisão é dotado de uma mesma força e energia vital.

Dessa forma, essas religiôes contribuem na construção da oikoumene mostrando a possibilidade de uma comunhão inter-religiosa como "uma nova realidade e uma nova consciência da unidade dos povos de Deus", a consciência de que "o ecumenismo verdadeiro pressupóe uma mais larga capacidade de acolhida, de percepção da presença viva do Deus sempre maior, pai e mãe de todos os povos" ${ }^{13}$. Mas, infelizmente, isso está ainda longe de indicar o atual jeito de crer e de viver das comunidades religiosas latino-americanas.

Inúmeras resistências ao diálogo e à cooperação entre fés se manifestam. No mundo cristão afirma-se, ainda, uma conjuntura eclesiástica marcada pela arrogância identitária, estão bem presentes as atitudes fundamentalistas e exclusivistas. São problemas reais, mas não devem obscurecer o sonho dialogal das comunidades. Experiências importantes de encontro, diálogo e comunhão também se manifestam e fazem história. Elas instauram uma radical crítica aos exclusivismos, "apontando a riqueza multifacetada da experiência do Deus que fala sob formas muito diversas e se faz presente em mediaçóes diferentes das que conhecemos" ${ }^{\prime 14}$. Isso precisa ser justificado teologicamente, o diálogo ecumênico e a teologia ecumênica exigem a acolhida da alteridade que se manifesta na diversidade religiosa latino-americana ${ }^{15}$.

\section{Por uma teologia ecumênica Latino-Americana}

Urge ler teologicamente as iniciativas de diálogo entre diferentes identidades culturais, religiosas e espirituais na América Latina, encaminhando-se para uma proposta articulada de uma teologia ecumênica latino-americana. Não podemos aqui desenvolver todos os elementos dessa teologia, apenas propomos algo que, esperamos, incentivem esforços nessa direção. A pesquisa terá que avançar no desenvolvimento de uma epistemologia própria, com definiçôes conceituais, regras linguísticas, princípios hermenêuticos e rigor metodológico que explicite a ecumenicidade da fé cristã para as igrejas dessa região.

\footnotetext{
${ }^{13}$ Teixeira, "Interpelação do diálogo inter-religioso para a teologia".

${ }^{14}$ Ibid.

${ }^{15}$ Frisotti, Passos no diálogo. Igreja católica e religióes afro-brasileiras, 57-69.
} 


\section{A inserção social do ecumenismo}

A partir da década de 60 do século XX, as igrejas evangélicas intensificam a aproximação da realidade social de forma a influir significativamente no seu pensar teológico. É exemplo disso a III Conferência Evangélica Latino-Americana (1969), que fortalece uma teologia baseada "na noçẫo da encarnação como modelo da missão", tratando da "encarnação da Igreja na vida e nos conflitos da sociedade".

A CELA III impulsiona o desenvolvimento de uma cristologia autóctone, uma eclesiologia e missiologia inseridas e uma antropologia libertadora. Nos anos 70, a União Latino Americana de Juventudes Ecumênicas afirmava "a opção por uma teologia que considerasse a libertaçáo sociopolítica dos povos do nosso continente como inseparável da redenção total que Cristo oferece" ${ }^{16}$. Outro exemplo desse período é a Fraternidade Teológica Latino-Americana, projetada como um ponto de encontro e uma plataforma que permitisse as igrejas entender melhor o Evangelho e sua pertinência, ante a situação crítica dos países latino-americanos.

No mundo católico, contribuíram para a inserção social da Igreja as orientaçôes do Vaticano II, sobretudo a Gaudium et spes, e as conferências do episcopado latinoamericano realizadas em Medellín (1968), Puebla (1979), Santo Domingo (1992) e Aparecida (2007) ${ }^{17}$. A perspectiva profética e transformadora, a opção preferencial pelos pobres, o modelo de Igreja comunidade eclesial de base, são os elementos mais expressivos da forma como o catolicismo assume o contexto sociopolítico como o lugar da presença da Igreja e do testemunho concreto do Evangelho da "vida plena em abundância”.

Com isso, o movimento ecumênico incorpora sempre mais a solidariedade social como algo urgente e condizente com a missão das igrejas. E é a partir da sensibilidade às vicissitudes do meio social que acontece o despertar para uma concepção de unidade entre as igrejas, desenvolvida no horizonte da solidariedade e da diaconia para com todas as pessoas que sofrem as consequências das estruturas sociais injustas ${ }^{18}$. Entáo percebe-se que "o ecumenismo supera os limites das entidades criadas pelas igrejas e que a tarefa conjunta é possível quando o compromisso é com todo o povo de Deus" ${ }^{19}$.

\footnotetext{
${ }^{16}$ Míguez, "De Rosario a Oaxtepec: los movimentos ecuménicos y la búsqueda de la unidad cristiana en América Latina”, 35-44.

${ }^{17}$ Ver Mejía, "El compromisso ecuménico de la Iglesia de América Latina en los documentos de Medelín", 245-250; Wolff, "O diálogo na Igreja e a Igreja do diálogo no Documento de Aparecida, 532-569; Wolff, "Puebla e a busca da unidade cristâ", 27-46.

${ }^{18}$ Ver Santa Ana, Ecumenismo e libertação.

${ }^{19}$ Plou, Caminhos de unidade. Itinerário do diálogo ecumênico na América Latina, 171.
} 
Esse fato sintoniza a prática ecumênica das igrejas com as concepçóes de ecumenismo apresentadas pelo diálogo intercultural e inter-religioso, vistos acima. E mostra a necessidade de desenvolver na América Latina uma teologia que apresente tanto as especificidades de cada diálogo, quanto as aproximaçóes e convergências de seus conteúdos e de seus fins.

\section{Primeiros passos na sistematização}

$\mathrm{Na}$ década de 60 do século $\mathrm{XX}$, a perspectiva da libertação torna-se o locus de convergência teológica entre diferentes tradiçôes eclesiais e uma nova hermenêutica latino-americana da fé cristã é gestada ecumenicamente. Em 1968, o presbiteriano brasileiro, Rubem Alves, defendia sua tese em Princeton, com o título Towards a Theology of Liberation. Em 1971, o católico peruano, Gustavo Gutiérrez, escrevia Teología de la Liberación. Duas tentativas de sistematização de um pensamento teológico latino-americano.

O ano de 1969 representa um marco histórico da ecumenicidade dessa teologia, no encontro entre o peruano Gustavo Gutiérrez e o brasileiro Rubem Alves, em Cartigny (Suíça), durante uma reunião promovida pela Sociedade Mista (do Vaticano e do CMI) para o Desenvolvimento e a Paz (Sodepax) ${ }^{20}$. No âmbito do CMI, a teologia da libertação se refletiu entre os anos 1968 a 1980, no comitê sobre Sociedade, Desenvolvimento e Paz (Sodepax), que funcionou como agência ecumênica, sob a responsabilidade da Comissão Pontifícia sobre Justiça e Paz, criada em 1967, e o CMI a partir das igrejas para a Participação no Desenvolvimento (CIPD) ${ }^{21}$. Esses fatos têm dois principais significados: a valorizaçáo por parte das igrejas europeias da teologia que emerge na América Latina; e o reconhecimento da ecumenicidade desse novo modo de pensar a fé.

Um importante número de teólogos fortalecem o pensar teológico ecumênico e libertador. O vemos em evangélicos como José Miguez Bonino, metodista argentino; Richard Shaull, presbiteriano norte-americano atuante no Brasil; nos uruguaios metodistas Júlio de Santa Ana e Emílio Castro; nos brasileiros luteranos Walter Altmann,

${ }^{20}$ Aqui Gutiérrez propôs pela primeira vez o tema da "libertaçáo" fora da América Latina (por ele apresentado anteriormente numa conferência no encontro nacional do Movimento Sacerdotal, em Chimbote - Peru, no mês de julho de 1968, publicada em Montevidéu, no ano de 1969 com o título Hacia una teología de la liberación). Em Cartigny (encontro realizado em novembro de 1969, organizado em por Sodepax, sobre o tema "Teologia e desenvolvimento") Gutiérrez reelaborou o texto de Chimbote, publicando-o ainda com o título Hacia una teología de la liberación (Lima, 1970), e em inglês com o título Notes on a Thology of liberation (Lausana, 1970). Em dezembro de 1971, Gutiérrez publica em Lima a primeira edição de Teología de la liberación.

${ }^{21}$ Plou, Caminhos de unidade. Itinerário do diálogo ecumênico na América Latina, 184. 
Gottfried Brakemeier, Martin N. Dreher. Da parte católica, o tema da libertação com notável perspectiva ecumênica é desenvolvido por José Comblin, Leonardo Boff, John Sobrino, Juan Luís Segundo, entre outros.

A ecumenicidade do pensar libertador mostra-se também pela interação entre teólogos católicos latino-americanos e teólogos protestantes europeus, como se vê na recepção da teologia de Moltmann em teólogos católicos da América Latina ${ }^{22}$. É importante observar, ainda, o fato de que os teólogos evangélicos abordam mais explicitamente o ecumenismo do que os teólogos católicos, o que talvez se explique pelo notório protagonismo do protestantismo no movimento ecumênico.

A dimensão ecumênica do pensar teológico latino-americano em perspectiva libertadora vai sendo cimentada no tempo pelo apoio de organizaçóes que promovem encontros de estudos e consultas sobre questóes pertinentes à vida das igrejas e da sociedade. São exemplos disso as iniciativas de organizaçôes como Igreja e Sociedade na América Latina (ISAL, 1962), a Comissão de Estudos de História da Igreja na América Latina (Cehila, 1973), e a Associação Ecumênica dos Teólogos do Terceiro Mundo (Asett, 1976), entre outras.

Assim, as origens próximas de uma teologia ecumênica na América Latina se encontram no contexto da criação da "teologia da libertação", de modo que há sintonia entre ser "ecumênico" e ser "libertador": "o caminho teológico libertador é ecumênico, nasceu ecumênico. Uma teologia da libertação que não fosse ecumênica, até seria um contrasenso" ${ }^{23}$. E isso implica também numa proximidade metodológica, mostrando que a ecumenicidade dessa reflexão se dá nos vários elementos que fazem do ato teológico uma tarefa que não é dever de uma só Igreja:

...considerando os grandes obstáculos a se suplantar na prática religiosa de todos os cristãos latino-americanos comprometidos; o pioneirismo da temática que esse novo pensar teológico apresenta; e a crise que se instalou nas igrejas cristâs históricas, a ilaçấo mais imediata é que o enfrentamento dos novos desafios exige uma postura ecumênica. ${ }^{24}$

Dessa forma, há um vínculo entre o movimento ecumênico latino-americano e os contextos sócio-eclesiais nos quais se origina, cresce e amadurece o novo pensar teológico nas igrejas do continente em perspectiva da libertação. A Conferência de Medellín (1968), da parte católica, e a III Conferência Evangélica Latino-Americana

${ }^{22}$ Kuzma. "A recepção da teologia protestante de Jurgen Moltmann no meio católico", 131.

${ }^{23}$ Asett, Documento de los teólogos latinoamericanos da la Segunda Asamblea General de la Asociación Ecuménica de Teólogos del Tercer Mundo”, 321.

${ }^{24}$ Bittencourt Filho, "Crítica teológica da economia política - Notas pastorais”, 29. 
(1969), da parte evangélica, mostram importantes convergências no tema da justiça e da prática eclesial libertadora ${ }^{25}$. Com ess"a convergência as igrejas exercitam a prática do diálogo, do companheirismo e da cooperação na reflexão da fé e na ação pastoral. E "essa práxis ecumênica aprofunda suas razóes teológicas por uma real cooperação entre teólogos e teólogas de diferentes igrejas, sintonizados no uso de novas categorias, sendo 'libertação' o eixo e também a perspectiva hermenêutica da fé cristâ”" ${ }^{26}$.

A teologia ecumênica se desenvolve sintonizada também com diferentes movimentos de libertação social, facilitando o diálogo e a ação que expressam uma comum sensibilidade às problemáticas sociais dos povos. Tal ecumenicidade ganha impulso pela nova atmosfera eclesial impulsionada pela renovação da leitura bíblica, da liturgia, e da ação missionária que abre espaços para o laicato, os movimentos jovens, as mulheres. Com isso a interação entre teólogos de diferentes tradiçóes eclesiais expressam a criatividade e a ousadia de uma reflexão que tenta abrir novos caminhos em nível eclesial e pastoral, inserindo a teologia no horizonte da oikoumene cristá.

\section{Ampliando os horizontes da teologia ecumênica}

A teologia ecumênica possui a tarefa ousada de qualquer teologia cristá: articular sistematicamente a compreensão do mistério de Deus revelado ao mundo em Jesus Cristo, tentando identificar entre as diversas formas de conceber a fé cristã os elementos de divergência e de comunhão. Busca discernir esses elementos e promover uma hermenêutica que supere os aspectos divergentes de modo a possibilitar a comunhão visível dos cristãos na Igreja una.

Isso tem sido a tarefa tradicional da teologia. Mas é importante ir além e mostrar como isso interage com expressões de fé não cristâs que também apresentam concepçóes da oikoumene que se busca como espaço comum para todos. Sem desconsiderar as fronteiras epistemológicas entre a teologia confessional das igrejas, a teologia ecumênica e a recente teologia das religióes, é preciso compreender que ambas precisam interagir quando se pensa na sustentação de uma proposta ampla de oikoumene.

Dessa forma, de um lado, é objeto da teologia ecumênica o comum a toda teologia cristá: Deus e seu mistério de amor salvífico manifestado ao mundo na pessoa de Jesus Cristo, acolhido na comunidade cristã que dele dá um testemunho comum. Aqui a teologia ecumênica busca compreender como deve ser a Igreja que Cristo quer.

\footnotetext{
${ }^{25}$ Brighenti, "A justiça em Medellín e as categorias da tradição eclesial libertadora”, 151-166.

${ }^{26}$ Wolff, "Medellín, o ponto de partida do ecumenismo na Igreja Católica na América Latina e no Caribe", 294.
} 
Por outro lado, perscrutando o mistério de Deus busca-se compreender como ele se manifesta em Cristo, mas para além do cristianismo e da Igreja.

A teologia faz, então, uma leitura do atual pluralismo cultural, religioso e espiritual e discerne os sinais do mistério crístico ali se manifestando. Questiona as situações de divisão doutrinal entre as igrejas, a falta de fraternidade solidária entre as religiōes, e as injustiças nas relaçôes entre os povos. E propóe a unidade da Igreja como um serviço para a fraternidade ecumênica entre igrejas, religiôes e culturas.

Não se trata de ter como objeto de análise o pluralismo religioso em si mesmo, o que é da competência da teologia das religiôes. Para realizar a sua tarefa sem incorrer em erros hermenêuticos e metodológicos que comprometa as especificidades das identidades, o que se quer da teologia ecumênica é que considere as implicações do pluralismo religioso e cultural para a concepção cristã da oikoumene.

Assim, é importante explorar as possibilidades de interação da práxis da fé cristã com outras formas de crer e com a vida sociocultural dos povos latino-americanos, e daí apontar para projetos comuns a serem realizados em vista de uma fraternidade ecumênica ampla. O desafio é como realizar essa tarefa contemplando diferentes formas religiosas de conceber e participar do diálogo. Será possível um construto epistêmico formado pelos diferentes sujeitos e suas formas de dialogar? Como fazer isso sem negar os sistemas epistemológicos construídos por cada perspectiva do diálogo?

É preciso buscar as respostas investigando a implicação da fé cristã para a cooperaçáo das religióes e a convivência na justiça e na paz entre as culturas e os povos. Isso significa compreender como deve ser e se organizar a Igreja que neste continente professa a fé em Cristo, para que seja "fermento na massa", "sal e luz" (cfr. Mt 5,14) e "instrumento do Reino" ( $L G 1)$ para todos. Assim fazendo, a teologia realiza a sua função de explicitar e justificar a ecumenicidade da fé cristã como contribuição e serviço para toda a oikoumene.

\section{Teologia das religiões indígenas e afro-americanas}

Os primeiros ensaios de uma teologia das religiōes latino-americana já vêm à luz²7. E esse esforço abre caminhos para uma teologia do diálogo inter-religioso com rosto latino-americano. A dificuldade para tal deve-se a vários fatores:

- Às religióes propriamente regionais, como as indígenas e afro-americanas, falta uma teologia suficientemente articulada: "Em nenhum caso é feito um

${ }^{27}$ Ver Vigil, Teologia do pluralismo religioso: para uma releitura pluralista do cristianismo; Tomita, Barros e Vigil, Pluralismo e libertação - Por uma teologia latino-americana pluralista a partir da fé cristã. 
estudo sistemático dessas religióes por si mesmas, da necessidade delas (ou não) da mediação salvífica de Cristo, nem um estudo pormenorizado do valor da revelação própria dessas religiōes e de seus livros sagrados" ${ }^{28}$.

- Um segundo fator é que os ensaios de teologia indígena e afro-americana se dáo na perspectiva da teologia da libertaçấo ${ }^{29}$. Mas sofrem a dificuldade de apresentar algo original. As aproximaçôes feitas com a teologia da libertação, mesmo se positivas, não dâo conta "de uma teologia com uma metodologia própria, peculiar, que não há de ser comparada com o conceito clássico ocidental de teologia, já que seu objeto e as perguntas a que respondem são outras" ${ }^{30}$.

- Em terceiro, o diálogo inter-religioso na América Latina em muito reproduz formas e conteúdos do diálogo que acontece também em outras regiôes do planeta e isso não permite responder às perguntas próprias do contexto. Assim, a ausência de uma teologia das religiôes no continente explica, ao menos em parte, a fragilidade do diálogo inter-religioso que acontece na região.

Para suprir tal carência, busca-se encontrar na teologia da libertação uma teologia das religióes ou princípios que sustentem o diálogo inter-religioso. A perspectiva libertadora é o horizonte maior no qual acontece tanto a reflexão teológica das religiôes, quanto a prática do diálogo inter-religioso. Mas, também aqui, a oikoumene inter-religiosa é pensada apenas como uma dimensão ou perspectiva da teologia da libertação.

Uma teologia das religiōes e do diálogo inter-religioso com categorias e estatuto epistemológico próprio é, ainda, inexistente em nosso meio. É significativo o esforço para apresentar na categoria "macroecumenismo" jeito latino-americano de fazer teologia das religióes e o diálogo inter-religioso ${ }^{31}$. Mas é uma categoria ainda a ser justificada cultural e teologicamente.

A questão a ser definida é como a perspectiva cristã da oikoumene dialoga com essas perspectivas. Se não busca construir uma oikoumene separada e exclusiva, o diálogo entre as igrejas precisa encontrar modos de interagir com outras formas de conceber a oikoumene. Assim, a história do movimento ecumênico precisa ser revista incorporando as iniciativas do diálogo inter-religioso, sem confundir pressupostos hermenêuticos e metodológicos próprios de cada episteme.

${ }^{28}$ Vigil, Teologia do pluralismo religioso: para uma releitura pluralista do cristianismo, 332.

${ }^{29} \mathrm{Da}$ Silva, "Pluralismo religioso y tradiciones religiosas africanas", 61-76.

${ }^{30}$ Vigil, Teologia do pluralismo religioso: para uma releitura pluralista do cristianismo, 333.

${ }^{31}$ Casaldaliga e Vigil, Espiritualidad de la liberación, 192-201; Vigil, Teologia do pluralismo religioso: para uma releitura pluralista do cristianismo, 333-343. 
Trata-se de incentivar o encontro dos habitantes dos diversos cômodos da mesma casa, entendendo que não basta cuidar do próprio quarto se é a casa inteira, planetária, que necessita de atenção. Afinal, estamos todos na mesma habitação, "tudo está estreitamente interligado no mundo" ( $L S 16)$, de modo que o específico cristão do ecumenismo não se opõe e nem é indiferente a outras especificidades. E se "o todo é mais do que as partes" ( $E G$ 235), as especificidades são apenas isso, e como tal conduzem à atenção ao todo, é este que precisa ser salvo.

\section{A contribuição pentecostal}

Por muito tempo, afirmou-se na América Latina que os cristãos pentecostais se opóem ao ecumenismo. Em grande parte isso é verdade, mas não é toda a verdade. Grande parte da história do pentecostalismo no continente é marcada por discursos e atitudes exclusivistas e fundamentalistas. Mas nos últimos tempos observa-se também que segmentos pentecostais se esforçam por rever essa postura e mostram-se parceiros do diálogo com outras expressóes de fé, dentro e fora do cristianismo.

Tal postura é ainda mais de indivíduos do que de comunidades pentecostais. Mas ela está ganhando expressão dentro e fora do pentecostalismo e já se manifesta de forma organizada por instituiçóes como a Rede Latino-Americana de Estudos Pentecostais - Relep, Comunhão Renovada de Evangélicos e Católicos no Espírito Santo - Creces, na Argentina, o Encontro de Cristãos na Busca de Unidade e Santidade - Encristus, no Brasil.

Quem imaginaria há poucos anos atrás um estudo sobre Ecumenismos e pente$\operatorname{costalismos}^{32}$, o diálogo inter-religioso na Assembleia de Deus? ${ }^{33}$ Ou que seria possível escrever sobre a relação entre pentecostalismos e cultura, política, gênero, economia, buscando um diálogo de aproximação entre essas realidades? ${ }^{34}$. Em nível continental Juan Sepúlveda ${ }^{35}$ e Bernardo Campos ${ }^{36}$ são teólogos pentecostais reconhecidos como incentivadores do ecumenismo latino-americano.

Portanto, o pentecostalismo também possui uma concepção da oikoumene que é importante ter presente e verificar como ela pode interagir com outras concepçóes e outras práticas ecumênicas. Esse é um grande desafio tanto para a teologia pentecostal

\footnotetext{
${ }^{32}$ Ver De Alencar, Ecumenismos e pentecostalismos. A relação entre o pescoço e a guilhotina?

${ }^{33}$ Ver De Lima, Assembleias de Deus e o Espirito Santo: história, teologia e diálogo.

${ }^{34}$ Ver De Oliveira, Ferreira e Fajardo, Pentecostalismos em perspectivas.

${ }^{35}$ Ver Sepulveda, Voces del pentecostalismo latinoamericano: identidade, teologia, historia.

${ }^{36}$ Campos e Consejo Latinoamericano de Iglesias, De la Reforma protestante a la pntecostalidad de la Iglesia. Debate sobre el pentecostalismo en América Latina.
} 
quanto para a teologia ecumênica em desenvolvimento. Cabe repetir aqui a pergunta sobre como o ecumenismo latino-americano, até então construído pelas igrejas chamadas "históricas", pode hoje integrar a contribuição pentecostal. Em âmbito mundial, essa contribuição acontece pelo Conselho Mundial de igrejas, onde se integram comunidades pentecostais. Mas essas mesmas comunidades resistem participar do diálogo realizado por instituiçóes similares na América Latina.

Uma explicação disso parece ser o fato de a Igreja Católica integrar oficialmente as organizaçôes ecumênicas do continente, o que não acontece no CMI. Mas não é tudo, pois constata-se dificuldades para as relaçôes ecumênicas dos pentecostais também com o protestantismo histórico. O fato é que as dificuldades precisam ser assumidas para serem superadas. Para que tal aconteça, é necessária uma disposição de todos os atores da oikoumene para compreender o que acima foi dito: afirmar o modo específico do diálogo sem exclusividade; e acolher as especificidades sem confusão. Onde não houver exclusividade e nem confusão das identidades, o modo de elas se expressarem enriquecerá a convivência na oikoumene, casa de todos.

\section{Princípio utópico do ecumenismo}

A tentativa a fazer é evitar a redução da riqueza semântica que o termo oikoumene apresenta, não identificando-o de forma totalizante com as aspiraçôes de pessoas, culturas, igrejas ou religióes. A questáo a ser respondida é se as iniciativas de diálogo entre as diferentes identidades encontram-se no horizonte da ecumene.

Esse horizonte se explicita de diferentes maneiras em cada uma das identidades em diálogo. Estas encaminham-se para a ecumene mas não são a ecumene. Em suas particularidades elas não exaurem a totalidade da realidade que a ecumene representa. A oikoumene transcende os horizontes de uma determinada perspectiva ou um horizonte do diálogo, é mais do que o diálogo propóe e nada exclui.

A ecumene é o espaço que se constrói pela interação entre as diferenças - pessoas, grupos ou naçóes, com suas culturas, credos, sistemas políticos e econômicos, com suas instituiçóes, ideologias, valores e padróes de comportamento, com suas motivaçóes, esperanças e temores. Esse espaço possui características multiformes justamente pela diversidade dos agentes que o constituem. Por essa razão, a sua natureza e os seus horizontes não estão definidos a priori, e nem o são a partir dos agentes que antecederam ou das características de apenas um dos grupos que atuam no seu interior.

A ecumene não apresenta nenhuma possibilidade de configuração definitiva, uma vez que está sempre aberta para acolher as contribuiçóes específicas dos novos agentes de cada época. Por isso são suas características fundamentais a dinamicidade, a pluralidade, a transcendência, a capacidade de refazer-se constantemente e assumir 
um "sempre mais", que supera a finitude do horizonte atual da sua configuração. Nela todos e tudo têm lugar, e se algum limite existe no seu horizonte, esses são os limites dos seus agentes.

Desse modo, o diálogo ecumênico é aquele que visa o entendimento sobre a ecumene, em todos os seus aspectos e dimensóes, envolvendo todos os seus agentes. Não é o diálogo que envolve apenas um grupo ou uma das suas características. No "ecumênico" a prioridade não é das particularidades, mas do todo. Obviamente, o todo não existe sem as partes, de modo que são as particularidades e especificidades dos grupos em diálogo que constroem o horizonte total da ecumene. Mas não se pode limitar o todo a uma das partes, de modo que não se pode limitar o ecumênico às motivaçôes, objetivos e interesses de apenas um dos grupos em diálogo.

Por essa razão, há que se superar os limites do universo de significado dado ao ecumenismo quando ele é identificado com uma perspectiva ou horizonte do diálogo. Todas as positivas interaçôes das diferenças podem encontrar-se no horizonte da oikoumene. E por essa razáo tanto o diálogo intereclesial quanto o inter-religioso ou inter-cultural podem ser designados como diálogo ecumênico.

\section{O princípio realista do ecumenismo}

Vemos, portanto, que "ecumenismo" tem, de um lado, um horizonte utópico, que indica a superação de todas as fronteiras da ecumene. É um movimento em contínuo refazer-se conforme as novas condiçóes e as novas exigências que se apresentam nos diferentes tempos e nas diferentes situaçóes. Mas, de outro lado, "ecumenismo" tem um princípio eminentemente prático/realista: é concebido a partir de um contexto específico de sujeitos e situaçóes que estabelecem critérios, limites, princípios de coerência para a prática ecumênica.

E não poderia ser diferente, pois a ecumene não é um princípio teórico ou uma realidade abstrata. $\mathrm{O}$ horizonte utópico encarna-se em diferentes realidades, e estas reconfiguram continuamente esse horizonte. Os fatores contextuais indicam o modo presente e realista da oikoumene. Historicamente, a partir do século XIX o conceito ecumene expressa os esforços de restituição da unidade no interior do universo religioso cristão e eclesiástico. E identifica-se com esse fato, a aspiração ecumênica limita-se a uma parcela da realidade que a compóe, o cristianismo.

Essa delimitação é legítima, pelo princípio realista do ecumenismo, na medida em que responde aos anseios de sujeitos e identidades sociais, culturais e religiosas concretas. Mas não determina de todo a realização futura da oikoumene, que se dará a partir de novas transformações e novas concepções que estão sempre por vir. $\mathrm{O}$ horizonte utópico ajuda a compreender que os elementos contextuais não exaurem 
o que poderá ser um verdadeiro ecumenismo. Assim, não pode haver cooptação do ecumenismo no mundo cristáo ou outro, de modo que o seu significado permanece aberto a experiências diversas que enriquecem a realização da oikoumene incluindo novos sujeitos, identidades e contextos.

Portanto, o significado original do termo oikoumene recebe conotações diversas a partir da sua associação com o conteúdo das motivaçôes de indivíduos, grupos e instituiçóes de um contexto. Essas conotaçôes indicam delimitaçóes do sentido de oikoumene. Este termo já não mais designa "o mundo habitado", mas "o modo" de habitar o mundo, ou um grupo dos habitantes ou sua perspectiva. Esse fato restringe a universalidade de oikoumene em dois principais horizontes: semântico, porque o seu significado se dá no interior de um determinado horizonte cultural ou religioso; prático, porque o seu conteúdo satisfaz apenas ao horizonte concreto da realidade que ele designa.

A realidade ecumênica passa a ser o modo como um determinado grupo a concebe. O risco é a oikoumene perder o seu aspecto utópico que a torna transcendente às realidades concretas. E o ganho é o fato de seu significado utópico realizar-se na concretude das relaçóes de um contexto presente, mesmo se este não o exaure.

\section{A nossa proposta}

Como há diferentes formas de situar-se na ecumene, há diversas compreensóes de ecumenismo. Essas compreensôes se legitimam pela coerência com a forma como as identidades se relacionam. Por isso, ao falar de ecumenismo faz-se necessário deixar claro o "contexto ecumênico" a partir do qual se elabora a fala. O que significa que é necessário uma delimitação desse conceito, sem com isso empobrecer o seu universo semântico. A riqueza desse universo está vinculada ao contexto que o sustenta, embora não seja por ele exaurido e permaneça aberto a outras formas de concepção, tanto pelas transformaçóes do próprio contexto, quanto em outros contextos.

Aqui utilizamos o conceito "ecumenismo" como expressão daquilo que o evangelista João mostra como um desejo de Jesus: "Que todos sejam um" (Jo 17, 21), ou seja, a unidade das discípulas e discípulos de Jesus. Vincular a categoria "ecumenismo" à "unidade cristâ" tem suas complexidades e para muitos pode parecer reducionismo do seu amplo universo semântico. Mas como toda concepçáo da ecumene é contextualizada, é importante explicitar que o significado desse vocábulo se legitima também pelo histórico do movimento ecumênico realizado por cristáos, igrejas e organizaçóes afins a partir do final do século XIX e, sobretudo, dos inícios do século XX.

O amplo significado do vocábulo oikoumene não deslegitima as contribuiçôes específicas dos diferentes sujeitos que a constroem. Ao contrário, promove e inclui a 
expressão própria de cada identidade na composição da oikoumene. A realidade total da oikoumene se enriquece pela contribuição das partes que a formam. Por isso, o ecumenismo cristão não é demodè. Ele se justifica tanto como exigência de uma das identidades que compóem a oikoumene; quanto como a natureza própria desta, que se faz afirmando as diferenças.

Sem atender a isso, não apenas as identidades particulares se frustram, como também a própria oikoumene fracassa como projeto de "casa comum" onde todos tem lugar. Assim, legitima-se o ecumenismo também como busca de unidade na fé cristã. É progredindo nessa busca que os cristãos melhor contribuirão para satisfazer as exigências de uma ecumene mais ampla.

Desse modo, estamos longe de um empobrecimento do conceito "ecumenismo" se considerarmos, ainda, as diversas dimensões do movimento ecumênico, notadamente: teológica, espiritual e social. Desenvolvendo essas dimensôes, o movimento ecumênico não permite que a busca da unidade cristã aconteça como privilégio de um grupo religioso, cristão, em relaçáo a outros grupos religiosos, ou como distanciamento da realidade social.

Há uma interação entre o diálogo ecumênico, o diálogo inter-religioso e o diálogo sociocultural, sem perdas das especificidades de cada uma das formas de dialogar. Não se trata, portanto, de afirmar um "micro-ecumenismo" em tensão a um "macroecumenismo", mas de perceber que diferentes formas do que chamamos de diálogo ecumênico configura suas razôes, objetivos e meios em estreita sintonia com a realidade dos dialogantes. A especificidade cristã não deslegitima as contribuiçôes específicas dos diferentes sujeitos da oikoumene. Ao contrário, promove a expressão própria de cada identidade, a realidade total da oikoumene se enriquece pela contribuição das partes que a formam. Por isso, o ecumenismo cristão não é demodè.

\section{Conclusão}

Propusemos neste estudo identificar os elementos que expressam a atual reconfiguração no movimento ecumênico latino-americano e as suas implicaçôes para a construção de uma teologia ecumênica latino-americana. A partir da pesquisa sobre o ecumenismo no Brasil, fez-se necessário investigar sobre o ecumenismo latino-americano para perceber como ecumenismo e teologia são duas realidades que se relacionam intrinsecamente.

Considerando a Conferência Missionária realizada no Panamá, em 1916, como o ponto de partida do movimento ecumênico na América Latina, constata-se que existe no continente um significativo percurso ecumênico já percorrido e, mesmo se os resultados são ainda parciais e provisórios, o diálogo até agora realizado constrói as bases 
para a continuidade das relações ecumênicas. Essas relações contam hoje com novos sujeitos e novas pautas nos diferentes contextos em que vivem os povos do continente.

Assim, o movimento ecumênico passa hoje por um processo de reconfiguração com a agregaçáo de novos elementos que redimensionam as concepçóes e as práticas ecumênicas, refazendo seus objetivos, seus métodos e suas finalidades. Desse modo, a perspectiva ecumênica se amplia para além do universo cristão. A continuidade do diálogo intra-cristáo não pode desconsiderar esse fato. E esse diálogo avança na medida em que souber estabelecer relaçóes com o pluralismo cultural e religioso do nosso tempo.

Por isso, é fundamental que a perspectiva cristã do ecumenismo saiba identificar os novos sujeitos, os novos conteúdos e os novos objetivos, bem como as novas concepçôes que emergem de ecumenismo para além do universo cristão. Daqui surgem vários desafios como, de um lado, a necessidade de fortalecer a perspectiva cristã do ecumenismo, integrando sempre mais os cristáos e suas igrejas nos esforços por um testemunho comum do Evangelho.

De outro lado, a perspectiva cristã do ecumenismo precisa interagir com outras concepçóes e práticas do diálogo, outros atores e outros objetivos oriundos das diferentes culturas e religióes das nossas sociedades, que apresentam significativas contribuiçôes para a construção da oikoumene.

Um terceiro desafio é justificar teologicamente a prática ecumênica realizada na América Latina, o que se faz alicerçando-a na perspectiva libertadora da teologia que surge no final dos anos 60 do século XX, ampliada pelas novas perspectivas teológicas oriundas do atual pluralismo cultural e religioso. Assim procedendo, será possível propor o ecumenismo como paradigma teológico, de modo que ele deixe de ser apenas "um tema específico" da teologia para se tornar o horizonte e o eixo no qual se desenvolve a reflexão de todo o sistema da fé cristá.

O ecumênico deve encarnar um amplo campo de diálogo e trabalho conjunto cujo potencial sociopolítico, cultural e teológico seja a visibilização de nossas sociedades, culturas, religióes e igrejas interagindo positivamente na construção de espaços comuns de convivência e de cooperação. Para isso, urge relançar o ecumenismo em nosso tempo e em nosso contexto continental, possibilitando à reflexão da fé uma via metodológica e hermenêutica com novas contribuições categóricas, novos horizontes e novas práticas que favoreçam para convergências e consensos na doutrina cristã e nos compromissos sociopolíticos, especificando a sua contribuição para a oikoumene que se constrói para além do cristianismo. 


\section{Referências}

Asett. "Documento de los teólogos latinoamericanos da la Segunda Asamblea General de la Asociación Ecuménica de Teólogos del Tercer Mundo", Oaxtepec, México, 7-14 de deciembre de 1986.

Becka, Michelle. Interculturalidade no pensamento de Raúl Fornet-Betancourt. São Leopoldo: Nova Harmonia, 2010.

Bittencourt Filho, José. "Crítica teológica da economia política - Notas pastorais". Em Por Uma nova teologia latino-americana - A teologia da proscrição, por Koinonia, 23-30. São Paulo: Paulinas, 1996.

Brighenti, Agenor. "A justiça em Medellín e as categorias da tradição eclesial libertadora”. Em Medellin: memória, profetismo e esperança na América Latina, organizado por Ney de Souza e Emerson Sbardelotti, 151-166. Petrópolis: Vozes, 2018.

Campos, Bernardo e Consejo Latinoamericano de Iglesias. De la Reforma protestante a la pntecostalidad de la Iglesia. Debate sobre el pentecostalismo en América Latina. Quito: CLAI, 1997.

Casaldaliga, Pedro e José María Vigil. Espiritualidad de la liberación. Quito: Verbo Divino, 1992.

Celam. Documento de Santo Domingo. Sáo Paulo: Loyola, 1992.

Da Silva, Antônio Aparecido. "Pluralismo religioso y tradiciones religiosas africanas". Em Por los muchos caminos de Dios. Desafios del pluralismo religioso a la teología de la liberación, editado por Asett, 61-76. Quito: Centro Bíblico Verbo Divino, 2003.

De Alencar, Gedeon Freire. Ecumenismos e pentecostalismos. A relação entre o pescoço e a guilhotina? São Paulo: Editora Recriar, 2018.

De Lima, Adriano. Assembleias de Deus e o Espirito Santo: história, teologia e diálogo. São Paulo: Reflexão, 2018.

De Oliveira, David Mesquiati; Ismael de Vasconcelos Ferreira Ismael; Maxwell Pinheiro Fajardo (orgs.). Pentecostalismos em perspectivas. São Paulo: Terceira Via/Relep, 2017.

Fornet-Betancourt, Raúl. Questóes de método para uma filosofia intercultural a partir da Ibero-América. São Leopoldo: Unisinos, 1994. 
. Interculturalidade. Crítica, diálogo e perspectivas. São Leopoldo: Nova Harmonia, 2004.

Frisotti, Heitor. Passos no diálogo. Igreja católica e religiōes afro-brasileiras. São Paulo: Paulus, 1996.

Hoornaert, Eduardo. Formação do catolicismo brasileiro 1550-1800. Petrópolis: Vozes, 1978.

Kuzma, Cesar. "A recepção da teologia protestante de Jurgen Moltmann no meio católico". Em Ecumenismo e reforma, organizado por Alessandro Rodrigues Rocha e Cláudio de Oliveira Ribeiro, 123-134. São Paulo, Paulinas, 2017.

Mejía, Jorge. "El compromisso ecuménico de la Iglesia de América Latina en los documentos de Medellin”. Em Medellín. Reflexiones en el Celam, por Secretariado General del Celam, 245-250. Madrid: Biblioteca de Autores Cristianos, 1977.

Míguez, Nestor. "De Rosario a Oaxtepec: los movimentos ecuménicos y la búsqueda de la unidad Cristiana en América Latina". Em Oaxtepec 1978: unidad y misión em América Latina, editado por CLAI (em formação), 121-131. San José, Costa Rica: CLAI, 1978.

Ortiz, Renato. A consciência fragmentada. São Paulo: Paz e Terra, 1980.

Padre Toninho. "Porque somos militantes desta causa". Instituto Cultural Kizomba, http://institutoculturalkizomba.blogspot.com/2012 1001 archive.html (acessado em 29 novembro, 2018).

Plou, Dafne Sabanes. Camihos de unidade. Itinerário do diálogo ecumênico na América Latina. São Leopoldo-Quito: : Sinodal-CLAI, 2002.

Quintero Pérez, Manoel. “Oikoumene: Venturas y desventuras en la antesala del tercer milênio”. Cristianismo y sociedad 33/124 (1995): 44-58.

Raiser, Konrad. "O Conselho Mundial e os novos desafios para o movimento ecumênico”. Estudos Teológicos, 34, n. 3 (1994): 276-281.

Santa Ana, Júlio. Ecumenismo e libertaão. Petrópolis: Vozes, 1987.

Sepulveda, Juan. Voces del pentecostalismo latinoamericano: identidade, teologia, historia. São Paulo: Relep, 2009.

Teixeira, Faustino. "Interpelação do diálogo inter-religioso para a teologia". Disponível em http://fteixeira-dialogos.blogspot.com/2010/04/interpelacaodo-dialogo-inter-religioso.html (acessado em 29 novembro, 2018). 
Tomita, Luiza E.; Marcelo Barros; e José María Vigil. Pluralismo e libertação - Por uma teologia latino-americana pluralista a partir da fé cristã. São Paulo: Loyola 2004.

Vigil, José Maria. Teologia do pluralismo religioso: para uma releitura pluralista do cristianismo. São Paulo: Paulus, 2006.

Westehlle, Victor. “Una sancta: a unidade da Igreja na divisão social”. Estudos teológicos 31/1 (1991): 29-46.

Wolff, Elias. "Medellín, o ponto de partida do ecumenismo na Igreja Católica na América Latina e no Caribe". Em Medellin: memória, profetismo e esperança na América Latina, organizado por Ney de Souza e Emerson Sbardelotti, 287-302. Petrópolis: Vozes, 2018.

. "O diálogo na Igreja e a Igreja do diálogo no Documento de Aparecida". Revista eclesiástica brasileira 68/271 (2008): 532-569.

_. "Puebla e a busca da unidade cristâ". Em Efemérides mexicana: estudios filosóficos, teológicos e históricos 109 (2019): 27-46.

Zwetsch, Roberto Ervino. “Teologias da libertação e interculturalidade”. Em Conviver: ensaios para uma teologia intercultural latino-americana, por R. E. Zwetsch, 107-128. Sáo Leopoldo: Sinodal/EST, 2015. 